\title{
Redesain pendidikan islam: perkembangan pendidikan pasca penerapan syari'at islam di aceh
}

\author{
Abidin Nurdin a,1,*, Sri Astuti A. Samad ${ }^{\text {b,2, }}$, Munawwarah b,3 \\ ${ }^{a}$ Universitas Malikussaleh, Jln. Tengku Chik Ditiro No. 26 Lancang Garam, 24351, Kota Lhokseumawe, Indonesia \\ ${ }^{\mathrm{b}}$ Universitas Islam Negeri Ar-Raniry, Jl. Syeikh Abdul Rauf Darussalam, 23111 Banda Aceh, Indonesia \\ ${ }^{1}$ abidin@unimal.ac.id*, ${ }^{2}$ sriastuti@arraniry.ac.id, ${ }^{3}$ munawwarah.samad@gmail.com \\ * Korespondensi Penulis
}

\section{ARTICLE INFO}

\section{Article history}

Received June 26, 2020

Revised June 26, 2020

Accepted June 27, 2020

Available Online June 30, 2020

Keywords

Syari'at

Pendidikan Islam

Aceh

Reedesain pendidikan islam

\section{ABSTRACT}

This study aims to discuss the redesign of Islamic education which is focused on the development of Islamic education after the Islamic shari'ah was formally applied in Aceh. As it is understood that the application of Islamic sharia is a part of the historical mandate, and has become a characteristic of the social and cultural order of the Acehnese people which is thick with religious values, the latter is then strengthened by law regulations from the central government. The method used is qualitative research with data collection techniques namely literature review, interviews and observations while the analysis technique uses tryangulation. The result is that since the implementation of Islamic sharia in Aceh there has been a redesign of Islamic education, which is to strengthen the three centers of education which are also based and synergized with Islamic sharia. The three education centers are: first, the (formal) school from elementary school but up to tertiary institutions; secondly, the community (non-formal), at the level of the village where there is a meunasah and the study center as a place of study of tauhid, fiqih and tasawuf; and third, family (informal) through family strengthening. Thus the tri education center is enriched with Islamic sharia values that shape human character and noble character.

Kajian ini bertujuan untuk membahas tentang redesain pendidikan Islam yang difokuskan pada perkembangan pendidikan Islam setelah syari'at Islam diterapkan secara formal di Aceh. Sebagaimana dipahami bahwa penerapan syari'at Islam merupakan bagian dari amanah sejarah, dan telah menjadi karaktersitik tatanan sosial dan budaya masyarakat Aceh yang kental dengan nilai-nilai agama, terakhir kemudian diperkuat dengan peraturan udang-undang dari pemerintah pusat. Metode yang digunakan adalah penelitian kualitatif dengan teknik pengumpulan data yaitu kajian literatur, wawancara dan observasi sedangkan teknik analisis memakai tryangulasi. Hasilnya adalah bahwa sejak penerapan syari'at Islam di Aceh terjadi redesain pendidikan Islam yaitu menguatkan tiga pusat pendidikan juga berbasis dan bersinergis dengan syar'at Islam. Tri pusat pendidikan tersebut yaitu: pertama, sekolah (formal) dari Sekolah Dasar tetapi sampai pada Perguruan Tinggi; kedua, masyarakat (non formal), pada level gampong yang terdapat meunasah dan balai pengajian sebagai tempat pengkajian ilmu tauhid, fiqih dan tasawuf; dan ketiga, keluarga (informal) melalui penguatan keluarga. Dengan demikian tri pusat pendidikan tersebut diperkaya dengan nilai-nilai syari'at Islam yang membentuk manusia berkarakter dan berakhlak mulia. 


\section{Pendahuluan}

Kajian mengenai syari'at Islam menarik untuk didiskusikan tidak hanya dalam koteks negara bangsa atau tata Negara tetapi juga dalam kontek pendidikan pendidikan Islam. Studi syari'at Islam hubungannya dengan pendidikan Islam dapat ditemukan misalnya; Muhammad (2003), Salim (2008), yang menegaskan bahwa lembaga pendidikan seperti UIN/IAIN memiliki kontribusi yang besar dalam pelaksanaan syari'at Islam di Aceh. Hal ini dapat dilihat dari tokoh-tokoh kampus baik sebagai intelektual maupun sebagai anggota Majelis Permusyawaratan ulama (MPU) dalam yang memberikan ide, gagasan, fatwa bahkan terlibat dalam membuat qanun (perda syari'at Islam).

Pada ranah yang sama, Idris (2002: 21), Nur Wahid (2004: 148) dan Budiman (2004: 13) mengatakan bahwa pendidikan yang berlandaskan syari'at dalam bentuk teori, kurikulum apalagi lembaga yang berlandaskan syariat tentulah sangat diperlukan. Sehingga akan melahirkan manusia yang memiliki etos kerja yang tinggi, kreatif, semangat revivalisme Islam dan membentuk keshalehan individu dan sosial serta pemahaman Islam yang rahmatan lil alamin.

Kemudian, Srimulyani, (2008) Mujiburrahman (2011) dan Abu Bakar (2013) menegaskan pentingnya pendidikan pada keluarga dan masyarakat sehingga melahirkan budaya pendidikan yang berbasis syari'at. Demikian pula perlunya perubahan paradigma menuju integrasi yang tidak mendikomikan ilmu-ilmu agama dan umum. Namun demikian yang perlu diingat menurut Daud (2002: 59-60) bahwa pendidikan syari'at yang diimplementasikan di Aceh harus memadukan antara keterampilan dasar (foundation skills) dan keterampilan hati (heart skills).

Sebagaimana diketahui bahwa penerapan syari'at Islam dalam konteks negara bangsa jauh hari sudah diminta oleh Teungku M. Daud Beureueh pada 17 Juni 1948 kepada Presiden Soekarno ketika datang ke Aceh, tetapi permintaan ini tidak dikabulkan. Daud Beureueh kecewa dan memuncak sehingga melakukan perlawanan dengan Jakarta yang kemudian mendirikan DI/TII. Pada tahun 1959 Aceh diberi gelar "istimewa", hal tersebut berdasarkan Keputusan Perdana Menteri Republik Indonesia No. 1/Missi/1959. Berdasarkan aturan inilah Daerah Aceh diberi izin untuk menyelenggarakan keistimewaan dalam tiga bidang yaitu bidang keagamaan, peradatan, dan pendidikan. Keputusan ini memberikan status istimewa kepada Aceh dalam artian dapat melaksanakan otonomi daerah yang seluas-luasnya terutama dalam tiga bidang tersebut (Nurdin, 2014: 291).

Selanjutnya disahkan Peraturan Daerah No. 1 Tahun 1963 Tentang Pelaksanaan Syiar Agama Islam dalam Daerah Istimewa Aceh dan Perda No. 1 Tahun 1966 tentang Pedoman Dasar Majelis Permusyawatan Ulama telah ada lembaga ulama. Meskipun lembaga ini tidak pernah betul-betul menjadi wadah resmi daerah karena telah ditetapkan jenis dan bentuknya oleh Pemerintah Pusat. Pemerintah tidak mendukung sepenuhnya misalnya dari segi keuangan hanya mendapat bantuan ala kadarnya karena belanja dan keuangannya hanya dicantolkan pada lembaga lain yang resmi (Abu Bakar, 2005: 35).

Sejalan dengan pembentukan lembaga ulama ini juga dibentuk Biro Pelaksanaan Unsur-Unsur Syariat Islam yang sering disingkat Biro UUSI yang bertugas untuk mengkoordinasikan dan melaksanakan berbagai kebijakan dan kegiatan yang berkaitan dengan pelaksanaan Syari'at Islam di Aceh. Tetapi biro inipun pada akhirnya terpaksa dibubarkan karena dalam nomenklatur pemerintah daerah yang disediakan oleh pemerintah pusat, tidak ada tempat untuk biro tersebut (Abu Bakar, 2005: 36).

Terkait pada hal tersebut di atas bahwa sejak masa Teungku Muhammad Daud Beureueh 1948, Missi Hardi 1958, Perda No. 1 Tahun 1963 yang membentuk Biro UUSI namun pelaksanaan syari'at Islam tidak pernah teraplikasi dengan sesungguhnya. Hal disebabkan karena politik otoritarianisme yang dimainkan oleh Soekarno dan Soeharto yang menyebabkan konfigurasi politik juga tidak memihak kepada keinginan masyarakat Aceh. Akibatnya produk hukum yang dihasilkan juga jelas akan bersifat otoritarian dan tidak demokratis.

Setelah kemerdekaan upaya melaksanakan syari'at Islam melalui lembaga peradilan yang mandiri dan berkuasa penuh termasuk sesuatu yang diupayakan sejak masa paling awal. Karena tuntutan yang terus menerus, maka Gubernur Sumatera melalui Surat Kawat Nomor 189 tanggal 13 Januari 1947 memberi izin kepada Residen Aceh membentuk Pengadilan Agama (Mahkamah Syar'iyah) dengan kewenangan yang penuh (tidak memerlukan pengukuhan dari Pengadilan Negeri) namun hanya terbatas dalam bidang kekeluargaan (meliputi nafkah, harta bersama, hak 
pemeliharaan anak, disamping perceraian dan pengesahan perkawinan) dan kewarisan (Nurdin, 2014: 292).

Perubahan sosial politik di Indonesia ketika memasuki masa reformasi turut berimbas ke daerah termasuk Aceh. Presiden BJ. Habibie menandatangani UU Nomor 44 Tahun 1999, tentang Penyelenggaraan Keistimewaan Aceh, yang meliputi bidang agama, adat, pendidikan dan peranan ulama. Selanjutnya UU No. 18 Tahun 2001 tentang otonomi daerah yang kemudian semakin memperkuat posisi Aceh dalam menyelenggarakan pemerintah secara luas. Berdasarkan aturan tersebut kemudian melahirkan lembaga yang dapat mendukung pelaksanaan syariat Islam yaitu: Dinas Syari'at Islam, Majelis Permusyawaratan Ulama, Wilayahtul Hibah, serta perubahan pengadilan Agama menjadi Mahkamah Syar'iyah dengan perluasan kewenangan (Feener, 2013: 286). Demikian pula Badan Pendidikan dan Pemberdayaan Dayah. Sejalan dengan itu maka pada tanggal 1 Muharram 1423 Hijriyah bertepatan dengan 15 Maret 2002 secara resmi syariat Islam dideklarasikan pada masa Gubernur Abdullah Puteh (Ibrahim, 2004: 83-94).

Pelaksanaan syari'at Islam diperkuat dengan lahirnya Undang-Undang Pemerintah Aceh (UUPA) Nomor 11 tahun 2006, sebagai bentuk aplikasi dari perdamaian antara Pemerintah RI dengan pihak Gerakan Aceh Merdeka (GAM) di Helsinki pada tanggal 15 Agustus 2005. Mengenai syari'at Islam, dalam UUPA pada Pasal 125 Ayat (2) disebutkan bahwa Syari'at Islam yang dimaksud pada ayat (1) meliputi ibadah, ahwal al-syakhsiyah (hukum keluarga), muamalah (hukum perdata), jinayah (hukum pidana), qadha (peradilan), tarbiyah (pendidikan), dakwah, syiar dan pembelaan Islam".

Oleh karena itu, syari'at Islam di Aceh tidak layak lagi diperdebatkan, apakah logis, rasional, atau perlu diberlakukan atau tidak. Karena jelas penerapannya merupakan amanah sejarah, hukum, sosial dan budaya Aceh yang mengharuskan untuk dilaksanakan. Maknanya, ketika syari'at Islam tidak diterapkan, pada saat yang bersamaan pihak-pihak yang tidak melaksanakannya telah melakukan pemberontakan terhadap sejarah, pelanggaran hukum, pengebirian realitas sosial dan pemasungan budaya Aceh itu sendiri (Nurdin, 2011: 1 dan Abbas, 2004).

Sejalan dengan itu, Sardar (2003: 117) menegaskan bahwa syariat merupakan metodologi yang dapat memecahkan masalah kemanusiaan dan membangun peradaban Islam di masa yang akan datang. Karena syari'at diyakini dapat menyelesaikan berbagai persoalan masyarakat Muslim serta menciptakan tatanan yang unggul dan adil. Untuk menciptakan tatanan tersebut maka langkah utama yang harus diambil adalah mengimplementasikannya dalam dunia pendidikan.

Pendidikan di Aceh disebutkan dalam UUPA Pasal 216 Ayat (1) dan (2) bahwa "Setiap penduduk Aceh berhak mendapat pendidikan yang bermutu dan Islami sejalan dengan perkembangan ilmu pengetahuan dan teknologi; Pendidikan sebagaimana dimaksud pada ayat (1), diselenggarakan berdasarkan atas prinsip-prinsip demokrasi dan keadilan dengan menjunjung tinggi hak asasi manusia, nilai Islam, budaya, dan kemajemukan bangsa".

Keberadaan UUPA pada prinsipnya membuka peluang yang lebih besar bagi Aceh untuk melaksanakan otonomi yang seluas-luasnya dan juga untuk menerapkan syariat Islam secara serius dan sistematis dalam seluruh dimensi kehidupan masyarakat, termasuk aspek pendidikan di dalamnya. Karenanya, keberadaan undang-undang tersebut memberikan landasan yang sangat kuat bagi Aceh untuk menerapkan syariat Islam, dan secara yuridis formal tidak ada alasan lagi bahwa syariat Islam di Aceh tidak dapat dilaksanakan dengan baik, sebab payung hukum sebagai tempat bersandar sudah begitu kokoh, tinggal kemauan dari pemerintah Aceh dan seluruh masyarakat untuk membuktikan bahwa syari'at Islam akan tegak di negeri ini.

Pada konteks penyelenggaraan pendidikan, pemerintah daerah dapat mengembangkan dan mengatur berbagai jenis, jalur dan jenjang pendidikan serta menambah materi muatan lokal sesuai dengan syari'at Islam. Sedangkan badan ulama yang disebutkan dalam UU Nomor 44 Tahun 1999 bersifat independen dan berfungsi sebagai lembaga yang memberikan pertimbangan terhadap kebijakan daerah, termasuk bidang pemerintahan, pembangunan dan kemasyarakatan serta tatanan ekonomi dan Islami.

Implementasi syari'at Islam tentunya bersifat multi dimensi, mencakup berbagai aspek dalam kehidupan masyarakat, tidak terkecuali bidang pendidikan. Khusus mengenai bidang pendidikan, pemerintah dalam upaya peningkatan kapasitas pendidikan daerah telah menetapkan melalui Qanun Nomor 23 Tahun 2002 Tentang Penyelenggaraan Pendidikan. Kebijakan ini dijalankan dalam 
rangka mengakomodir dan mengimplementasikan sistem pendidikan yang berlandaskan Syariat Islam di negeri ini. Hal ini sebagaimana dituangkan dalam Pasal 12 yang menyebutkan bahwa: "Sistem Pendidikan Provinsi Nanggroe Aceh Darussalam adalah pendidikan yang berdasarkan sistem pendidikan nasional yang disesuaikan dengan nilai-nilai Sosial Budaya Daerah serta tidak bertentangan dengan Syari'at Islam".

Mencermati penjelasan pasal 12 tersebut, ada tiga aspek yang harus diperhatikan dalam sistem pendidikan di Aceh, yaitu: pertama, sistem pendidikan nasional tetap menjadi patron dan standar dalam sistem pendidikan yang dilaksanakan di Aceh, artinya seluruh proses pelaksanaan, pengembangan dan peningkatan pendidikan mesti sejalan dan berada dalam bingkai sistem pendidikan Nasional. Kedua, aspek sosial budaya (adat istiadat) dan seluruh nilai-nilai lokal (local value) atau kearifan lokal (local wisdom) menjadi potensi daerah yang patut dihargai dan menjadi bahagian dalam mewarnai sistem dan isi pendidikan di Aceh. Ketiga, syariat Islam harus dijadikan sebagai dasar dalam pembangunan pendidikan. Seluruh aspek pendidikan yang dilaksanakan di Aceh mesti dijiwai serta tidak boleh bertentangan dengan nilai-nilai syari'at Islam (Mujiburrahman, 2011: 135).

Implementasi pendidikan berbasis syariat Islam secara konkret dapat diaplikasikan dalam proses pendidikan dengan memperhatikan dua dimensi, yaitu: Pertama, paradigma dan sistem pendidikan yang dirumuskan mencakup keseluruhan tahapan proses pendidikan manusia baik pada fase pendidikan dalam keluarga, sekolah dan masyarakat. Kedua, dari segi materi dan tujuan pendidikan mestilah berorientasi pada pembentukan dan penyiapan manusia yang sempurna dan berkualitas baik ditinjau dari segi keagamaan maupun kenegaraan, sehingga memiliki makna dan nilai lebih baik pada tataran kehidupan di dunia maupun dalam kehidupan di akhirat kelak. Dimensi pertama lebih menekankan pada proses pendidikan yang berlangsung di tiga pusat pendidikan, informal, formal dan nonformal. Sementara dimensi kedua tertuju pada orientasi dan tujuan dari proses pendidikan itu sendiri (Mujiburrahman, 2011: 135).

Berdasarkan beberapa kajian tersebut, maka tulisan ini akan membahas mengenai perkembangan pendidikan Islam di Aceh pasca penerapan syari'at Islam. Argumen utama yang ingin dibangun adalah pendidikan Islam merupakan pilar utama dalam menopang pelaksanakan syari'at Islam. Tanpa pendidikan Islam, mustahil syari'at Islam dapat teraplikasi dengan baik. Studi ini menggunakan pendekatan pendidikan Islam sebagai alat analisis dalam mengkaji perkembangan pendidikan Islam setelah syari'at Islam diterapkan secara formal di Aceh.

\section{Metode}

\subsection{Jenis Penelitian}

Jenis penelitian ini merupakan penelitian kualitatif, yaitu untuk menjelaskan, menguraikan dan menganalisis secara mendalam hasil penelitian yang diperoleh dari hasil wawancara dan observasi dengan para informan dan responden. Penelitian kualitatif merupakan prosedur penelitian yang menghasilkan data deskriptif berupa kata-kata tertulis atau lisan dari orang-orang dan perilaku yang dapat diamati dan diarahkan pada latar dan individu tersebut secara holistik (Moleong, 1997: 3).

\subsection{Waktu dan Tempat Penelitian}

Penelitian ini berlangsung antara bulan Mei-Oktober 2019. Lokasi penelitian yang dipilih adalah Kota Banda Aceh, Kota Lhoksuemawe, Aceh Besar dan Aceh Tamiang. Pemilihan Kota Banda Aceh dengan alasan karena terdapat perguruan tinggi besar yaitu UIN Ar-Raniry dan merupakan ibu kota Provinsi yang dapat menjadi barometer pelakasanaan syari'at Islam. Kota Lhokseumawe juga terdapat perguruan tinggi yakni Universitas Malikussaleh. Sedangkan Aceh Besar sebagian besar daerah pesisir dan pedalaman dan Aceh Tamiang berbatasan dengan Sumatera Utara.

\subsection{Teknik Pengumpulan Data}

Litterature review, teknik ini dipakai untuk memperoleh informasi yang lengkap tentang perlembangan pendidikan Islam pasca pelaksanaan syari'at Islam di Aceh. Untuk memperoleh gambaran dan data yang komprehensif tentang berbagai aspek yang berkaitan dengan masalah ini, maka telaah terhadap berbagai sumber wajib dilakukan. Data yang dimaksud dapat berupa dokumen pembelajaran, kurikulum, buku, jurnal, laporan penelitian, aturan hukum, ensiklopedi, artikel, koran dan sebagainya (Moleong, 1997: 219). 
Wawancara, Wawancara adalah bentuk perbincangan, seni bertanya dan mendengar yang termasuk favorit dalam penelitian kualitatif, bentuk pertanyaan yang dipakai adalah tidak terstruktur (Denzin dan Lincoln, 2009: 495). Teknik ini digunakan untuk memperoleh data dari informan kunci (key informan). Data yang diperoleh dari informan kunci ini, dengan menggunakan sistem purposive sampling. Purposive sampling adalah teknik pengambilan sampel dan sumber data dengan pertimbangan tertentu, maksudnya informan yang dianggap lebih paham dan mengetahui masalah yang sedang dikaji sehingga ia dipilih menjadi informan. Informan kunci yang dimaksud adalah, dosen, mahasiswa, Dinas Pendidikan Dayah Aceh, wilayatul hisbah (polisi syari'at) dan masyarakat.

Observasi, teknik ini dilakukan untuk memperoleh data lapangan yang bersifat pengamatan atau kehadiran peneliti secara langsung. Observasi dilakukan untuk mendapatkan data langsung dari lapangan yang menjadi obyek penelitian ini dengan mengandalkan kepekaan peneliti dalam mengamati berbagai fenomena yang terjadi pada fokus penelitian. Pengamatan langsung juga memungkinkan peneliti memahami situasi-situasi yang rumit dan dalam kasus-kasus tertentu, di mana teknik komunikasi tidak memungkinkan, maka teknik pengumpulan data ini sangat bermanfaat (Moleong, 1997: 125).

\subsection{Teknik Analisis Data}

Teknik analisis data yang digunakan adalah tryangulasi. Yaitu kajian yang terdapat dalam literatur (dokumentasi), wawancara dan hasil observasi lapangan atau biasa dianalisis. Analisis ini melibatkan pengerjaan, pengorganisasian, pengklasifikasian, pemecahan dan sintetis data serta pencarian pola, pengungkapan hal penting sehingga penulisan laporan menjadi mendapatkan hasil yang holistik dan universal. Hal ini dilakukan setelah data semuanya terkumpul.

\section{Hasil dan Pembahasan}

Untuk mempermudah implementasi syari'at maka dibutuhkan pendesainan ulang pendidikan Islam. Redesain yang dimaksud di sini adalah merancang kembali format pendidikan yang selama ini tidak hanya dikotomi antara lembaga pendidikan umum dan agama, tetapi juga jauhnya jarak antara tiga pusat pendidikan. Karena itu, di samping menggabungkan kedua lembaga pendidikan tersebut, juga mendorong tiga pusat pendidikan (tri pusat) agar dapat bersinergis secara efektif, yaitu sekolah (formal) masyarakat (non formal) dan keluarga (informal) (An-Nahlawi, 1995 dan Hasbullah, 2009).

\subsection{Sekolah (Formal)}

Sebagaimana dipahami bahwa pendidikan memiliki peranan yang cukup penting dan sentral dalam menerapkan syari'at Islam di Aceh. Agar orang-orang Aceh mampu memberdayakan orang yang tertindas, mencerahkan dan tersadarkan dari kemusyrikan. Model pendidikan yang patut diimplementasikan dalam mendukung penerapan syariat Islam adalah pendidikan yang memadukan antara dayah (pesantren) dan pendidikan umum (Idris, 2002: 21).

Pendidikan di sekolah yang bersifat formal tentunya memiliki dimensi yang berbeda dengan pendidikan dalam keluarga dan masyarakat. Di sekolah aktifitas pendidikan berlangsung dalam suatu institusi resmi yang dikelola dengan sistem yang baik dan profesional. Sejalan dengan semangat otonomi khusus Aceh, maka otonomi dalam hal pendidikan seyogyanya mendapat tempat yang luas untuk dilaksanakan. Terutama yang berkaitan langsung dengan aspek syari'at Islam, harusnya memungkinkan sekolah-sekolah di Aceh mulai diperkenalkan dan diterapkan syari'at Islam dengan lebih mengedepankan pembinaan daripada penghukuman (Srimulayani, 2008: 6).

Lembaga pendidikan formal merupakan institusi yang berada di garda depan dalam menerapkan pendidikan Islam yang berbasis syari'at Islam. Lembaga yang dimaksud adalah mulai jenjang pendidikan TK hingga Perguruan Tinggi, baik sekolah Islam maupun yang umum. Meski demikian problem utama yang harus segera diselesaikan saat ini adalah masalah integrasi syari'at Islam dalam kurikulum masing-masing lembaga.

Sebagai contoh di Sekolah Dasar di Kabupaten Pidie, dilakukan pembelajaran Arab Melayu (Arab Jawoe) dengan menggunakan metode halaqah (guru membaca murid mendengarkan) dan peer tutoring (tutor sebaya). Kitab-kitab yang digunakan misalnya Kitab tauhid, Kitab Akhlak, Bidayatul Muhtadi (fiqih), Masaail Muhtadi (fiqih). Proses pembelajaran ini kemudian melahirkan karakter siswa seperti; memperkuat tauhid, rajin ibadah, patuh kepada guru, patuh kepada orang tua. Kendala 
yang dihadapi terkait dengan metode pembelajaran dan waktu pembelajaran yang dapat diatasi oleh guru secara bersama (Samad, 2018: 511).

Hal ini dapat dilihat pada pesantren modern seperti Ma'had Ulumul Qur'an, Kota Langsa, Pidie dan Aceh Besar, Dayah Jeumala Amal, Pidie Jaya dan Dayah Modern Ruhul Islam Anak Bangsa, Dayah Umar Diyan (Aceh Besar) Dayah Darul Ulum (Banda Aceh) Dayah Insan Qurani dan Dayah al-Athiyah (SMP-SMA plus hafal Qur'an) di Aceh Besar. Belakang kemudian muncul sekolah umum yang mengambil model pesantren dalam bentuk asrama (Islamic Boarding School), yaitu, SMA Modal Bangsa (Banda Aceh), SMA Fajar Harapan (Aceh Besar), Fatih School (SD-SMA Banda Aceh, dibangun oleh Turki), al-Fityan (Aceh Besar). Disusul lembaga pendidikan mulai tingkat PAUD dan TKIT-SMPIT (Yayasan al-Azhar), SDIT Nurul Fikri, SDIT Nurul Islah (Banda Aceh).

Model pendidikan yang mengadopsi sistem pesantren tersebut mulai muncul dan berkembang setelah penerapan syari'at Islam. Realitas ini seperti yang telah dipaparkan oleh Azra (2000: 73) bahwa terjadi kebangkitan "sekolah elit muslim" atau "santrinisasi" dengan istilah, "sekolah Islam" atau "sekolah Islam unggulan" pada akhir tahun 1990-an dan awal 2000-an terutama di pulau Jawa misalnya: Sekolah al-Izhar (Pondok Labu), SMU Insan Cendikia (Serpong) dan SMU Madania (Parung). Meskipun realitas ini terjadi agak lambat terjadi di Aceh, hal ini disebabkan karena konflik yang berkepanjangan. Praktis model pendidikan ini berkembang setelah konflik dan sesudah tsunami sekitar tahun 2004-2005.

Sedangkan dilembaga pendidikan Tinggi misalnya di UIN Ar-Raniry materi syari'at Islam di Aceh sudah dijadikan mata kuliah khusus sejak tahun 2015. MD (Dosen sekaligus tim perumus Mata Kuliah Studi Syari'at Islam di Aceh) menjelaskan bahwa hal dilakukan untuk memberikan pemahaman sekaligus sosialisasi kepada mahasiswa tentang syariat Islam di Aceh, karena di dalamnya dikaji tentang sejarah, lembaga, qanun yang terkait dengan syari'at Islam (Wawancara, 13 Agustus 2019). Pemahaman syari'at Islam cukup penting agar terjadi internalisasi secara baik pada mahasiswa dan dunia akademik. Hal diakui MS, seorang mahasiwa UIN Ar-Raniry dari negeri Jiran, Malaysia mengakui bahwa jika dibandingkan dengan penerapan Syariat Islam di Aceh dan Malaysia. Maka saya berpendapat bahwa bebeeapa aspek cukup baik di Aceh, misalnya dalam hal aturan perundang-undangan yang di Aceh disebut qanun, maka ini cukup jelas dan cukup baik. Hal ini terbukti dengan adanya orang Malaysia yang melakukan studi banding ke Aceh untuk mempelajari qanun dan penerapan Syariat Islam secara umum di Aceh (Wawancara, 22 Juni 2019).

Menurut Mukhlisah dan Hayati (2019: 35) bahwa lahirnya mata kuliah studi Syari'at Islam di Aceh dalam kurikulum UIN Ar- Raniry dilatar belakangi oleh beberapa faktor yaitu; (1) perubahan nomenklatur lembaga. IAIN Ar-Raniry resmi menjadi UIN Ar-Raniry sejak dikeluarkannya Peraturan Presiden Nomor 64 Tahun 2013 dan Peraturan Menteri Agama (PMA) Republik Indonesia No 12 Tahun 2014 yang perubahan ini berdampak pada sistem lembaga yang salah satu unsurnya adalah kurikulum. Salah satu perubahan kurikulum adalah dengan internalisasi mata kuliah Studi Syariat Islam di Aceh. (2) Mata kuliah Studi Syariat Islam di Aceh dipandang sebagai karakteristik atau kekhasan yang dimiliki daerah Aceh yang perlu diajarkan dalam lembaga pendidikan tinggi, dan (3) Syariat Islam di Aceh dinilai sangat urgen untuk dikaji secara akademik disebabkan banyak persoalan syariat perlu kepada pengkajian-pengkajian dan yang mampu melakukannya adalah perguruan tinggi Islam.

Selain di UIN Ar-Raniry, internalisasi syari'at Islam juga terjadi di Universitas Malikussaleh di Kota Lhokseumawe. Menurut RY, (seorang Dosen di Unimal) bahwa materi-materi atau tema-tema syari'at Islam di Aceh dimasukkan sebagai pembahasan dalam mata kuliah Pendidikan Agama di Universitas Malikussaleh, Aceh. Hal ini berdampak pada peningkatan pemahaman syariat Islam di perguruan tinggi umum di Aceh (Wawancara, 23 Juni 2019). Hal ini dapat dilihat dari pengakuan RR, salah seorang mahasiswa Universitas Malikussaleh yang berasal dari luar Aceh, (Medan Sumatera Utara) mengenai pengaruh syari'at Islam terhadap pergaulan sehari-hari. Ia mengatakan baha pergaulan laki-laki dan perempuan cukup terjaga di bandingkan ketika saya masih di Medan, di sana apalagi malam minggu maka laki-laki akan datang ke rumah perempuan, bahkan ada yang keluar rumah berdua dengan mengendarai sepeda motor. Hal ini membuka peluang untuk berbuat maksiat (Wawancara, 22 Juni 2019).

Selain masalah pergaulan, AS, seorang mahasiswa Universitas Malikussaleh yang berasal dari Padang, Sumatera Barat juga mengakui bahwa pakaian perempuan di Aceh lebih sopan dari pada di 
luar Aceh. Ia mengatakan bahwa pakaian perempuan cukup tertutup dan nyaris tidak ada yang membuka aurat. Jadi bagi kami sebagai laki-laki terjaga pandangannya untuk tidak melihat hal-hal yang dilarang. Jika di laur Aceh, kita melihat kemanapun kami memandang aurat, atau pakaian yang tipis yang membangkitkan gairah nafsu (Wawancara, 22 Juni 2019).

Demikian pula sejak 2011 pihak Dinas Syariat Islam juga melakukan sosialisasi dan penguatan aqidah bagi sekolah-sekolah umum terutama SMP dan SMA diseluruh Aceh. Buku-buku pegangan syari'at Islam (semacam buku saku) bagi anak sekolah dibagikan secara gratis. Akan halnya program pendidikan diniyah bagi sekolah umum. Guru-guru dalam program tersebut direkrut secara ketat dan yang mempunyai kompetensi agama yang kuat dananya diberikan langsung oleh Kabupaten/Kota melalui Dinas Pendidikan. Hal ini dilakukan untuk mengimbangi jumlah jam pelajaran agama yang kurang di sekolah umum.

\subsection{Masyarakat (Non Formal)}

Masyarakat Aceh dikenal cukup kental dengan nilai-nilai syariat Islam, sehingga dapat disimpulkan sebagai totalitas dari ajaran Islam sendiri, maka Islam menjadi pandangan hidup (way of life). Pandangan hidup inilah yang mempengaruhi seluruh aktivitas masyarakat termasuk budaya. Karena pandangan hidup seseorang akan mempengaruhi cara berpikir dan cara berperilaku dan berinterkasi dengan sesama manusia, kesemuanya merupakan bagian dari budaya. Karena pandangan hidup orang Aceh adalah Islam, maka sangat wajar jika Islam sangat berpengaruh dalam budaya dan adatnya (Nurdin, 2013: 140).

Sejak syari'at Islam diterapkan di Aceh pendidikan secara informal yang dilakukan oleh masyarakat semakin meningkat. Hal ini dapat dilihat dengan semakin ramainya shalat berjama'ah di masjid dan meunasah (mushallah), balai pengajian, majelis taklim (Abbas, 2014: 25. Bahkan di beberapa kabupaten muncul kelompok dan perkumpulan yang berorintasi pada pengembangan agama. Seperti Jama'ah Subuh setiap pekan disertai ceramah, kelompok zikir, hal ini dapat dilihat di Kota Banda Aceh, Sabang, Pidie, Lhokseumawe. Demikian pula kegiatan keagamaan seperti, pengajian TPA bagi anak-anak, pengajian majelis taklim, juga pengajian TASTAFI (Tasawuf, Tauhid dan Fiqih) yang diprakarsai oleh kalangan Dayah (Pesantren). Pengajian Tastafi biasanya menghadirkan ulama dari Dayah MUDI Mesra Salamanga seperti Abu Mudi (Teungku Hasanol Basri) dan Tu Sop (Teungku Muhammad Yusuf Abdul Wahab) (Serambi Indonesia, 6 Januari 2017).

Kondisi seperti ini juga diakui oleh Ibrahim Latif (Kepada Dinas Syariat Islam Langsa) bahwa sejak penerapan syari'at Islam masyarakat semakin sadar untuk belajar dan mengkaji agama. Pengajian Al-Qur'an di Masjid, meunasah, balee (balai) bahkan di rumah terus berjalan. Pengajian dilakukan pada sore dan malam hari, sore sesudah Ashar dan sesudah magrib sampai Isya. Para santri yang mengaji pada sore hari, tidak mengaji lagi pada malam hari. Perhatian pemerintah terhadap pengajian bakda magrib juga cukup baik, bahkan di Langsa ada 66 gampong pada tahun 2013 honor imam gampong ditanggung oleh Dinas Syariat Islam Provinsi Aceh, saat ini hanya 25 gampong saja. Selebihnya ditanggung oleh APBK Langsa 41 gampong. Bahkan disetiap gampong ada imam dusun juga diberikan honor oleh pemda, salah satu dari imam dusun adalah mengadakan pengajian termasuk kepada anak-anak. Di samping itu baitulmal juga memberikan honor kepada para guru TPA/TPQ (Laporan Penelitian PKPM, 2014).

Sampai saat ini hampir setiap gampong di Aceh terdapat pengajian keagamaan yang dipusatkan di meunasah (mushallah). Imum meunasah memberikan pengajian terkait dengan ilmu tauhid, ilmu fiqih dan pengajian al-Qur'an bagi anak-anak. Di samping meunasah, juga ada balai pengajian yang dipimpin oleh teungku (ulama) di gampong yang diikuti oleh santri dari gampong (desa) setempat maupun dari luar. Menurut Zulkhairi (2019: 395) di Aceh Besar sampai saat ini terus dilakukan pengajian dan pembelajaran agama seperti tauhid, fiqih dan tasawuf. Pengajian ini memakai kitabkitab Arab-Melayu yang dikarang para ulama di masa merupakan warisan penting dari budaya keilmuan Islam yang masih menjadi referensi utama pembelajaran Islam masyarakat muslim hingga saat ini.

Semakin membaiknya penerapan syari'at Islam dalam konteks masyarakat diakui oleh MSY, salah seorang anggota WH (Wilayatul Hisbah/Polisi Syariat) Kota Banda Aceh. Ia mengatakan bahwa pada awal-awal penerapan Syari'at Islam tahun 2002-2004, sampai pada saat tsunami dan rekonstruksi dan rehabilitasi Aceh, 2004-2006 saat ini cukup banyak perkembangan. Prilaku dan 
pergaulan bebas antara laki-laki dan perempuan telah banyak perubahan, masyarakat juga sudah mulai sadar akan pentingnya Syari'at Islam. Contoh ditempat-tempat wisata pantai di Aceh, justru pengelola, atau penjual makanan dan minuman yang mengingatkan masyarakat agar tidak melalukan hal-hal yang melanggar agama. Dampak dari penerapan Syariat Islam saat ini telah banyak perubahan, masyarakat tidak seenaknya lagi melakukan pelanggaran, seperi perilaku pergaulan bebas dan mabuk-mabukan (Wawancara, 27 Juni 2019).

Sejalan dengan itu, berdasarkan hasil observasi di beberapa lokasi wisata yang biasanya menjadi tempat muda-mudi berdua-duaan juga lokasi konser musik juga menunjukkan ketaatan pada aturan qanun. Dahulu tempat wisata di Banda Aceh dan Aceh Besar beroperasi sampai malam hari seperti di Ulee Lhee, Lampuuk, saat ini tempat tersebut hanya dibuka sampai sebelum waktu magrib. Hal ini untuk mengurangi maksiat antara laki-laki dan perempuan. Demikian pula ketika diadakan konser yang menampilkan penyanyi dari luar seperti Jakarta, maka penonton laki-laki dan perempuan dipisahkan, tempat keluar dan masuk serta tempat menonton tidak bercampur antara laki-laki dan perempuan (Hasil Observasi, Juli 2019).

Penerapan syari'at Islam di Aceh juga mendorong terbentuknya Dinas Pendidikan Dayah Aceh sebelumnya juga didirikan Dinas Syariat Islam yang nampaknya hanya di Aceh saja ada dinas tersebut, di luar tidak ada. Menurut BD (Dinas Pendidikan Dayah Aceh) bahwa Dinas Pendidikan Dayah bertujuan untuk memberikan pembinaan seperti kurikulum, pembinaan guru dan bantuan pembangunan dayah. Sedangkan jumlah bantuannya tergantung tipe dayah yang bersangkutan, semakin banyak santri dayah tersebut akan juga akan menentukan banyak bantuan dari pemerintah (Wawancara, 20 Juni 2019).

Pada konteks ini dapat dilihat bahwa tradisi pendidikan Islam dalam masyarakat Aceh yang berbentuk dayah, meunasah dan balai pengajian yang terbukti memberikan kontribusi penting dalam perkembangan pendidikan Islam sejak masa kolonial, pasca kemerdekaan sampai saat ini. Hal ini kembali menguat pasca pelaksanaan syari'at Islam di Aceh.

\subsection{Keluarga (In Formal)}

Aktivitas pendidikan keluarga merupakan model pendidikan preventif yang memiliki akar yang kokoh dalam pembentukan karakter atau internal awareness untuk membangun komitmen menjalankan nilai-nilai ajaran Islam dari dalam pribadi anak. Proses pendidikan dalam keluarga berlangsung sepanjang masa, tak terkecuali setelah seorang anak menempuh pendidikan formal di sekolah. Pendidikan di sekolah tidak kalah pentingnya dari pendidikan keluarga (Srimulyani, 2008: $5)$.

Mengingat pendidikan sekolah yang bersifat formal tentunya memiliki dimensi yang berbeda dengan pendidikan dalam keluarga dan masyarakat. Di sekolah aktifitas pendidikan berlangsung dalam suatu institusi resmi yang dikelola dengan sistem yang baik dan profesional. Sejalan dengan semangat otonomi khusus Aceh, maka otonomi dalam hal pendidikan sebaiknya mendapat tempat yang luas untuk dilaksanakan. Terutama yang berkaitan langsung dengan aspek syariat Islam, harusnya memungkinkan sekolah-sekolah di Aceh mulai diperkenalkan dan diterapkan syari'at Islam dengan lebih mengedepankan pembinaan daripada penghukuman (Srimulyani, 2008: 6).

Selain itu, yang lebih utama dalam penerapan syariat Islam adalah melakukan penguatan dan proteksi terhadap keluarga. Dinas Syariat Islam bekerjasama dengan Kementerian Agama Provinsi Aceh, Mahkamah Syar'iyah dan Dinas registrasi dan Kependudukan Aceh melakukan istbath nikah terhadap lebih dari 100 pasangan suami istri yang belum mempunyai buku nikah. Hal ini disebabkan oleh konflik yang berkepanjangan dan tsunami yang berdampak pada tidak adanya akta nikah ratusan pasangan di seluruh Aceh. Istbath nikah merupakan langkah yang cukup urgen untuk melegalkan pernikahan yang berakibat pada perlindungan anak dan istri dan anak. Anak akan terlindungi jika orang tuanya memiliki akta nikah karena dengan mudah anak akan mendapatkan akta kelahiran. Dengan akta kelahiran tersebut anak mudah memperoleh pendidikan, beasiswa, bantuan lainnya dan terproteksi secara hukum. Sebaliknya jika anak tidak mempunyai akta kelahiran ia tidak mudah mendapatkan akses pendidikan, beasiswa, syarat untuk mendaftar Polisi dan TNI. Langkah inilah yang disebut sebagai penguatan keluarga terhadap problema kependudukan yang berdampak pada pendidikan anak.

Sejalan dengan itu, terkait dengan pendidikan dalam keluarga, pembinaan keluarga sebagaimana dilakukan oleh Kementrian agama dan Dinas Syariat Islam terus dilakukan kursus calon pengantin 
bagi pasangan yang ingin menikah, agar pada saat mereka telah berumah tangga terbentuk keluarga yang memiliki pemahaman agama yang baik. Demikian juga akan lebih mudah membentuk keluarga yang sakinah, mawaddah, dan rahmah serta terhindar dari konflik dan perceraian (Na'mah, 2016: 147). Di samping itu, menurut penjelasan MA, salah seorang Ibu Rumah Tangga di Aceh Tamiang yang merupakan wilayah perbatasan Aceh dan Medan bahwa peraturan yang diterapkan di Aceh terkait dengan perilaku dan akhlak yang baik, jelas mampu mencegah dan menghindari perbuatan buruk. Contoh kecil saja, di Aceh ketika akan keluar rumah seorang perempuan wajib mengenakan jilbab, demikian pula antara laki-laki dan perempuan yang bukan muhrim tidak boleh berdua-duan, maka masyarakat akan terhindar dari pergaulan bebas (Wawancara, 2 September, 2019).

Memang harus diakui bahwa setelah penerapan syari'at Islam hal yang cukup menonjol adalah pemakian jilbab bagi perempuan yang cukup merata dihampir setiap daerah dari kota sampai ke pelosok. Demikian pula intensitas perjudian dan mabuk-mabukkan juga mengalami penurunan. Karena ketiga hal tersebut diatur dalam qanun (semacam perda) Aceh sejak 2012-2013 yang kemudian diverisi diperbaiki pada 2014. Ketiga qanun tersebut berdampak pada terdidiknya masyarakat untuk menjauhi hal-hal yang menimbulkan penyakit masyarakat dan kriminalitas seperti, perjudian, mabuk-mabukan dan pergaulan bebas.

\section{Simpulan}

Proses pendidikan yang dijalankan dan berlangsung pada tiga pusat pendidikan tersebut harus sustainable dan bersinergi. Keberfungsian tiga pilar pendidikan ini memberi pengaruh positif terhadap pembentukan karakter masyarakat secara umum dan anak didik secara khusus. Namun sebaliknya, apabila ketiga pilar pendidikan ini tidak berjalan secara sinergis dan belum berfungsi secara baik, maka akan membawa dampak tersendatnya proses pembentukan karakter peserta didik secara khusus dan masyarakat secara umum. Oleh karena itu, disinilah letak pentingnya redesain pendidikan Islam sebagai solusi untuk memperkuat pelaksanaan syari'at Islam di Aceh. Redesaian ini tidak hanya menguatkan tiga pusat pendidikan tetapi juga berbasis dan bersinergis dengan syar'at Islam. Tri pusat pendidikan tersebut yaitu: pertama, sekolah (formal) dari Sekolah Dasar sampai pada Perguruan Tinggi; kedua, masyarakat (non formal), pada level gampong yang terdapat meunasah dan balai pengajian sebagai tempat pengkajian ilmu tauhid, fiqih dan tasawuf; dan ketiga, keluarga (informal) melalui penguatan keluarga. Dengan demikian tri pusat pendidikan diperkaya dengan nilai-nilai syari'at Islam yang membentuk manusia yang berkarakter dan berakhlak mulia. Melalui model pendidikan berbasis syari'at Islam yang teraktualisasi dalam proses pendidikan secara total dan menyeluruh di keluarga, sekolah dan masyarakat, memberi ruang dan kesempatan yang luas untuk membentuk karakter dan kepribadian anak sesuai dengan tuntutan nilai-nilai Islam. Sehingga pada akhirnya, orientasi dan tujuan akhir aktifitas pendidikan untuk mewujudkan individu (pribadi muslim) dan anggota masyarakat (komunitas muslim) yang baik, berakhlak mulia, berkarakter, berilmu dan profesional dapat dicapai dengan sempurna.

\section{Daftar Pustaka}

Abbas, S. (at. al). (2014). Presepsi Masyarakat Terhadap Pelaksanaan Syariat Islam di Aceh, Banda Aceh: Dinas Syari'at Islam Aceh.

Abu Bakar. (2013). Pendidikan Islam isspiTantangan dan Prospektif di Wilayah Syariat Islam Aceh, Jurnal Pencerahan Majelis Pendidikan Daerah Aceh, Vol. 7, No. 1.

Abubakar, A. (2005). Syari'at Islam di Provinsi Nanggroe Aceh Darussalam: Paradigma, Kebijakan dan Kegiatan, Banda Aceh: Dinas Syari'at Islam di Provinsi Nanggroe Aceh Darussalam.

An-Nahlawi, A. (1995). Pendidikan Islam di Rumah, Sekolah dan Masyarakat, (Terjemahan), Jakarta: Gema Insani Press.

Azra, A. (2000). Pendidikan Islam: Tradisi dan Modernisasi Menuju Milleum Baru, Jakarta: Logos.

Budiman, N. (2004). Kontribusi Pendidikan dalam Kerangka Pelaksanaan Syariat Islam, Makalah Annual Conference Program Pasca Sarjana IAIN/UIN Se-Indonesia, 1-5 Desember di Banda Aceh. 
Daud, D. (2002). Pendidikan berakar Syariat dalam Fairus M. Nur (editor), Syariat di Wilayah Syariat: Pernik-Pernik Penerapan Syariat Islam di Nanggroe Aceh Darussalam, Banda Aceh: Dinas Syariat Islam Aceh.

Feener, R. M. (2013). Social Engeneering Through Shari'a: Islamic Law and State-Directed Da'wa In Comtemporery Aceh, Journal Indonesian Law Revew, Year 3, Vol. 3, SeptemberDecember.

Hasbullah. (2009). Dasar-Dasar Ilmu Pendidikan, Jakarta: Rajawali Press.

Ibrahim, I. (2004). Dinamika Pelaksanaan Syariat Islam di Provinsi Nanggroe Aceh Darussalam, dalam Syahrizal (editor), Kontekstualisasi Syariat Islam di Nanggroe Aceh Darussalam (Banda Aceh: Ar-Raniry Press.

Idris, S. (2002). Mengembang Amanah Allah: Reaktulisasi Syariat Islam dan Masa Depan Pendidikan di Aceh dalam Fairus M. Nur (editor), Syariat di Wilayah Syariat: Pernik-Pernik Penerapan Syariat Islam di Nanggroe Aceh Darussalam, Banda Aceh: Dinas Syariat Islam Aceh.

Moleong, L.J. (1997). Metode Penelitian Kualitatif, Bandung: Rosda Karya.

Muhammad, R.A. (2003). Revitalisasi Syari'at Islam di Aceh: Problem, Solusi dan Implementasi Menuju Pelaksanaan Hukum Islam di Nanggroe Aceh Darussalam, Jakarta: Logos Wacana Ilmu.

Mujiburrahman. dkk. (2011). Pendidikan Berbasis Syariat Islam, Banda Aceh: Dinas Syari'at Islam.

Mukhlisah dan Hayati. (2019). Internalisasi Mata Kuliah Studi Syari'at Islam Di Aceh Dalam Kurikulum UIN Ar- Raniry Banda Aceh. An-Nuha: Jurnal Kajian Islam. Vol. 6, No. 1, Juli.

Na'mah, U. (2016). Pentingnya Peran Suscatin (Kursus Calon pengantin) dalam Membendung Laju Perceraian), Yustisia: Jurnal Pemikiran Hukum dan Hukum Islam, Vol. 7, No. 1, Juni 2016.

Nur Wahid, H. (2004). Menerapkan Syariat Islam dalam Bidang Sosial dan Pendidikan dalam Salim Segaf al Jufri (et. al), Penerapan Syariat Islam di Indonesia: antara Peluang dan Tantangan, Jakarta: Global Media.

Nurdin, A. (2013). Revitalisasi Kearifan Lokal di Aceh: Peran Budaya dalam Menyelesaikan Konflik dalam Masyarakat, Jurnal Analisis, Vol. VIII, No. 1 Juni.

Nurdin, A. (2014). Studi Agama: Konsepsi Islam dalam Menjawab Pelbagai Persoalan Kemanusiaan, Aceh Besar: Sahifah dan Pustaka Larasan.

Nurdin, A. (et. al). (2011). Syariat Islam dan Isu-Isu Kontemporer, Banda Aceh: Dinas Syariat Islam Aceh.

Qanun 14 tentang Penyelenggaran Pendidikan Aceh Tahun 2014.

Salim, A. (2008). Challenging The Seculer State: The Islamization of Law In Modern Indonesia, Honolulu: University of Hawai'i Press.

Samad. SAA. (2018). Pembelajaran Arab Melayu dan Pengaruhnya Terhadap Pembentukan Karakter Siswa di Sekolah Dasar Kabupaten Pidie, Aceh, Jurnal Ekspose, Volume 17, Nomor 1, Januari-Juni.

Sardar, Z. (2002). Kembali ke Masa Depan: Syariat sebagai Metodologi Pemecahan Masalah (Terjemahan), Jakarta: Serambi.

Serambi Indonesia, Tu Sop Gantikan Abu MUDI Isi Pengajian TASTAFI di Mesjid Raya, Jumat, 6 Januari 2017.

Srimulyani, E. (2008). Filosofi Pendidikan Berbasis Syariat Dalam Education Networks, Banda Aceh: Dinas Syariat Islam Provinsi Nanggroe Aceh Darussalam.

Undang-Undang Republik Indonesia Tentang Pemerintahan Aceh Nomor 11 Tahun 2006, Banda Aceh: Dinas Informasi dan Komunikasi Provinsi Nanggroe Aceh Darussalam. 
Zulkhairi. T. (2019). Pembelajaran Kitab Arab-Melayu di Aceh Besar Sebagai Proses Transfer Ilmu Agama Islam dan Upaya Menjaga Budaya, Jurnal Mudarrisuna, Vol. 9 No. 2 JuliDesember. 